Jurnal e-GiGi (eG), Volume 2, Nomor 2, Juli-Desember 2014

\title{
GAMBARAN PENGETAHUAN STAIN GIGI PADA PEROKOK DI KELURAHAN BAHU LINGKUNGAN V
}

\author{
${ }^{1}$ CH. Putri Amin Sinaga \\ ${ }^{2}$ dr B.S Lampus \\ ${ }^{3}$ Ni Wayan Mariati
${ }^{1}$ Kandidat Skripsi Program Studi Kedokteran Gigi Fakultas Kedokteran Universitas Sam Ratulangi
${ }^{2}$ Fakultas Kedokteran Universitas Sam Ratulangi
${ }^{3}$ Program Studi Kedokteran Gigi Fakultas Kedokteran Universitas Sam Ratulangi
Email: christina_sinaga91@yahoo.com

\begin{abstract}
The stain is a pigmented deposits in the teeth surface and is one of the aesthetic problem. Smooking increaces one factor contributing to the occutence of multiple disordersin in the oral cavity, one of which can cause tooth stain on the tooth surface. The habit of smooking cigarettes include the type, duration of smooking and number of cigarettes smoked a day. The purpose of this study to determine the knowledge of stain teeth in smokers in kelurahan Bahu lingkungan V. This is a descriptive study with cross-sectional approach. The research instrumen used was a questionnaire containing some questions about stain teeth. The result is 25 of the subject $(29,4 \%)$ have a good knowledge, 39 of the subject (45,9\%)enough knowledge and 21 of the subject (24,7\%) poor knowledge. Based on this study, the are some suggestions, one of it is to keep the good knowledge and reduce smooking to prevent the foemation of tooth stain on tooth surface.
\end{abstract}

Keywords: stain of the teeth, knowledge, smoker.

\begin{abstract}
Abstrak: Stain gigi adalah deposit berpigmen pada permukaan gigi dan merupakan salah satu masalah estetik. Kebiasaan merokok meningkatkan salah satu faktor penyebab terjadinya beberapa kelainan di rongga mulut, salah satunya dapat menimbulkan stain gigi pada permukaan gigi. Kebiasaan merokok meliputi jenis rokok, lama merokok dan jumlah rokok yang dihisap per hari. Tujuan dari penelitian ini untuk mengetahui pengetahuan tentang stain gigi pada perokok di kelurahan Bahu lingkungan V. Penelitian ini bersifat deskriptif dengan pendekatan cross-sectional. Instrumen penelitian yang digunakan ialah kuesioner yang berisi tentang beberapa pertanyaan tentang stain gigi. Hasilnya ialah sebanyak 25 responden $(29,4 \%)$ mempunyai pengetahuan baik, 39 responden $(45,9 \%)$ mempunyai pengetahuan cukup dan 21 responden (24,7\%) mempunyai pengetahuan kurang. Berdasarkan penelitian ini, terdapat beberapa hal yang disarankan antara lain mempertahankan pengetahuan yang sudah cukup baik dan mengurangi kebiasaan merokok agar tidak terjadinya pembentukan stain gigi pada permukaan gigi.
\end{abstract}

Kata kunci: Stain gigi, pengetahuan, perokok.

Rokok merupakan silinder dari kertas berukuran panjang antara $70-120 \mathrm{~mm}$ (bervariasi tergantung negara) dengan diameter $10 \mathrm{~mm}$ yang berisi daun-daun tembakau yang telah dicacah. Rokok dibakar pada salah satu ujungnya dan dibiarkan membara agar asapnya dapat dihirup lewat mulut pada ujung lainnya., Merokok juga merupakan salah satu faktor penyebab terjadinya beberapa kelainan rongga mulut seperti penyakit periodontal, keratosis rokok, Stomatitis nikotina (sariawan akibat nikotin), bercak snuff dipper (luka pada pengunyahan tembakau), karsinoma verukosa, eritroleukoplakia dan speckled eritropleukoplakia, karsinoma sel skuamosa dan melanosis perokok. ${ }^{3}$

Kebiasaan merokok meningkatkan risiko timbulnya berbagai penyakit seperti penyakit jantung dan gangguan pembuluh 
darah, kanker paru-paru, kanker rongga mulut, kanker laring, kanker esofagus, bronkhitis, tekanan darah tinggi, impotensi serta gangguan kehamilan dan cacat pada janin. Namun tetap saja pada kenyataannya, kebiasaan merokok ini sulit dihilangkan dan jarang diakui responden sebagai suatu kebiasaan buruk. ${ }^{1,2}$

Penelitian World Health Organisation (WHO) menunjukkan, merokok dapat merugikan semua organ tubuh manusia. Setiap tahun di dunia terdapat 5 juta orang yang meninggal karena penyakit yang disebabkan merokok. Kalau tidak dikontrol, angka itu akan naik 10 juta sampai tahun 2020. Jumlah perokok di dunia sekarang sekitar 1,3 milliar, diantaranya 650 juta orang akan cepat tutup usia karena merokok. Keadaan tersebut lebih parah lagi di negara berkembang, karena naiknya terus konsumsi tembakau. Kini satu diantara setiap dua kasus kematian ada kaitannya dengan merokok. Statistik menunjukkan, proporsi perokok kelompok usia 13-15 tahun anak remaja di seluruh dunia telah mendekati $20 \%{ }^{4}$

Dari survey awal yang dilakukan oleh peneliti, ada sebanyak 299 pria di kelurahan Bahu lingkungan $\mathrm{V}$ yang berumur 15-50 tahun, dimana data tersebut di dapat dari kantor kelurahan. Pria di kelurahan Bahu lingkungan $\mathrm{V}$ banyak yang mengonsumsi rokok. Hal tersebut dipengaruhi oleh lingkungan dan pekerjaan. Berdasarkan hal tersebut peneliti tertarik untuk melakukan penelitian tentang gambaran pengetahuan stain gigi pada perokok di kelurahan Bahu lingkungan $\mathrm{V}$ karena belum adanya data statistik mengenai gambaran pengetahuan stain gigi pada perokok di kelurahan Bahu lingkungan V. Hasil penelitian ini nantinya diharapkan dapat meningkatkan kesehatan gigi dan mulut seseorang dengan usaha memberikan pengetahuan tentang stain gigi. Rumusan masalah bagaimanakah gambaran pengetahuan stain gigi pada perokok di kelurahan Bahu lingkungan V. Tujuan penelitian Untuk mengetahui gambaran pengetahuan stain gigi pada perokok di kelurahan Bahu lingkungan V. Manfaat penelitian sebagai informasi dan bahan masukan tentang pengetahuan stain gigi pada perokok dan sebagai dasar untuk mengembangkan studi selanjutnya dalam bidang ilmu kedokteran gigi dasar.

Manfaat penelitian ini adalah sebagai data atau bahan yang dapat memberikan data mengenai gambaran pengetahuan stain gigi pada perokok di kelurahan Bahu lingkungan $\mathrm{V}$ serta menambah dan memperluas wawasan tentang stain gigi pada perokok.

\section{METODE PENELITIAN}

Jenis penelitian ini merupakan penelitian yang bersifat deskriptif dengan pendekatan cross sectional study. Tempat dan Waktu penelitian dilakukan di Kelurahan Bahu lingkungan V Manado pada bulan Januari 2014. Populasi dalam penelitian ini yaitu seluruh perokok di kelurahan Bahu lingkungan $\mathrm{V}$ yang berjumlah 85 orang. Penelitian ini dilakukan dengan menggunakan metode total sampling yaitu mengambil semua perokok yang termasuk dalam sampling frame untuk dijadikan sebagai sampel yaitu sebanyak 85 orang. Kriteria inklusinya adalah perokok yang berumur 15-50 tahun, bersedia dengan sukarela dijadikan sebagai subjek penelitian, bersikap kooperatif selama pengambilan data (di tandai dengan informed consent). Kriteria esklusinya adalah bersikap nonkooperatif selama pengambilan data. Variabel penelitian adalah pengetahuan dan stain gigi.

Definisi operasional penelitian ini adalah pengetahuan tentang stain gigi ialah apa yang diketahui masyarakat akan noda warna kecoklatan yang menempel pada permukaan gigi pada perokok. Untuk mengukur pengetahuan perokok digunakan 10 item pertanyaan, dalam bentuk pertanyaan tertutup. Setiap pertanyaan diberi skor 1 untuk jawaban tahu dan 0 untuk jawaban tidak tahu. Setelah seluruh kuesioner dinilai, maka tingkat pengetahuan dikelompokkan berdasarkan kategori berikut baik apabila nilai yang diperoleh $>75 \%$ dari nilai tertinggi, sedang apabila nilai yang diperoleh $40-75 \%$ dari nilai tertinggi, dan kurang apabila nilai yang diperoleh $<40 \%$ dari nilai tertinggi. Berdasarkan kategori 
tersebut, penilaian dalam kuesioner dimodifikasi sebagai berikut antara lain; Tingkat pengetahuan baik dengan nilai 8-10, tingkat pengetahuan cukup dengan nilai 4-7 sedangkan tingkat pengetahuan kurang pada nilai 0 -3.

Stain gigi gigi ialah warna yang menempel di atas permukaan gigi biasanya terjadi karena pelekatan warna makanan, minuman, ataupun kandungan nikotin khususnya pyridine yang merupakan substansi penghasil stain gigi. Instrumen penelitian yang akan digunakan dalam penelitian ini ialah kuesioner. Pelaksanaan penelitian dan pengambilan data. Pertimbangan etik izin perorangan dimintakan dari perokok di kelurahan Bahu lingkungan $\mathrm{V}$ yang akan dijadikan subjek penelitian, setelah mendapat persetujuan barulah penelitian dilakukan dengan memberikan kuesioner untuk dijawab. Pengambilan data data primer diperoleh dari kuesioner yang diedarkan pada perokok di kelurahan Bahu lingkungan $\mathrm{V}$ yang menjadi sampel penelitian. Data diperoleh langsung melalui kunjungan ke rumah-rumah sampel penelitian. Data sekunder berupa identitas kelurahan dan jumlah penduduk yang diperoleh dari profil kelurahan.

Uji validitas dilakukan sebelum kuesioner dibagikan kepada subjek penelitian. Uji validitas dilakukan untuk mengetahui sejauh mana instrumen kuesioner yang dibuat dapat mengukur apa yang seharusnya diukur. Hasil dari uji validitas dinilai dengan menggunakan Pearson's correlation. Uji validitas dan realibilitas diuji pada populasi non subjek di kelurahan Bahu lingkungan V sebanyak $30 \%$ dari jumlah sampel penelitian yaitu sebanyak 26 orang. Setelah diuji didapati 10 soal yang valid dan reliabel. Data diolah secara manual dan disajikan dalam bentuk tabel distribusi.

\section{HASIL PENELITIAN}

Kelurahan Bahu merupakan salah satu kelurahan yang terletak di daerah kecamatan Malalayang. Luas kelurahan Bahu sebesar $885.000 \mathrm{~m}^{2}$ yang terbagi menjadi 9 lingkungan. Batas wilayah kelurahan Bahu sebagai berikut sebelah utara berbatasan dengan pantai Malalayang, sebelah timur berbatasan dengan kelurahan Kleak, sebelah barat berbatasan dengan kelurahan Malalayang I timur, sebelah selatan berbatasan dengan kelurahan Batu Kota. Kelurahan Bahu lingkungan $\mathrm{V}$ memiliki penduduk sebanyak 640 orang yang terdiri dari 299 orang laki-laki dan 341 orang perempuan.

Tabel 1. Distribusi jumlah penduduk

\begin{tabular}{lc}
\hline \multicolumn{1}{c}{ Penduduk } & n \\
\hline Laki-laki & 299 \\
Perempuan & 341 \\
Jumlah & 640 \\
\hline
\end{tabular}

Subjek yang diteliti pada penelitian ini ialah perokok di kelurahan Bahu lingkungan $\mathrm{V}$ dengan jumlah subjek penelitian sesuai dengan perhitungan sampel berjumlah 85 responden. Distribusi frekuensi responden berdasarkan umur dapat dilihat pada Tabel 2.

Tabel 2. Distribusi frekuensi responden berdasarkan umur

\begin{tabular}{lcc}
\hline Umur & $\mathbf{N}$ & $\mathbf{\%}$ \\
\hline 15-35 tahun & 77 & $90,6 \%$ \\
$36-50$ tahun & 8 & $9,4 \%$ \\
\hline \multicolumn{1}{c}{ Jumlah } & 85 & $100 \%$ \\
\hline
\end{tabular}

Subjek penelitian berdasarkan umur sebagian besar 15-35 tahun yang berjumlah 77 responden $(90,6 \%)$ sedangkan umur 3650 tahun berjumlah 8 responden $(9,4 \%)$. Hasil dari kuesioner yang diberikan kepada perokok di kelurahan Bahu lingkungan V dapat dilihat pada Tabel 3. 
Tabel 3. Distribusi frekuensi responden berdasarkan kuesioner

\begin{tabular}{llccc}
\hline \multirow{2}{*}{ No } & \multicolumn{1}{c}{ Pengetahuan } & \multicolumn{2}{c}{ Tahu } & \multicolumn{2}{c}{ Tidak } \\
Tahu
\end{tabular}

Berdasarkan pengetahuan stain gigi disebabkan dengan merokok 61 (71,7\%) responden menjawab tahu dan menjawab tidak tahu sebanyak 24 responden (28,3\%). Jumlah merokok mempengaruhi proses cepat lambatnya pembentukan stain gigi dengan 39 responden (45,9\%) menjawab tahu dan menjawab tidak tahu sebanyak 46 responden (54,1\%). Lamanya merokok dapat menyebabkan penebalan stain gigi dengan 51 responden (60\%) menjawab tahu dan 34 responden (40\%) menjawab tidak tahu. Merokok menimbulkan kelainan rongga mulut dengan 44 responden (51,8\%) menjawab tahu dan 41 responden $(48,2 \%)$ menjawab tidak tahu. Stain gigi menimbulkan hasil pembakaran stain gigi dengan 43 responden (50,6\%) menjawab tahu dan 42 responden $(49,4 \%)$ menjawab tidak tahu. Stain gigi dapat membuat permukaan gigi menjadi kasar dengan 64 responden $(75,3 \%)$ menjawab tahu dan 21 responden $(24,7 \%)$ menjawab tidak tahu.

Iritasi terus menerus akibat pembakaran tembakau menyebabkan penebalan pada jaringan mulut dengan 22 responden (25,9\%) menjawab tahu dan 63 responden (74,1\%) menjawab tidak tahu. Semua jenisjenis rokok dapat menyebabkan stain gigi dengan 55 responden (64,7\%) menjawab tahu dan 30 responden (35,3\%) menjawab tidak tahu. Penggunaan produk tembakau dan kopi dapat menyebabkan stain gigi dengan 48 responden (56,5\%) menjawab tahu dan 37 responden (34,5\%) menjawab tidak tahu. Orang yang merokok selama hidupnya stain gigi dapat masuk ke lapisan gigi dan sukar untuk dihilangkan dengan 58 responden $(68,2 \%)$ menjawab tahu dan 27 responden $(31,8 \%)$ menjawab tidak tahu.

Secara keseluruhan, sebagian besar responden sebanyak 39 responden (45,9\%) mempunyai pengetahuan cukup, 25 responden $(29,4 \%)$ mempunyai pengetahuan baik dan sebanyak 21 responden (24,7\%) mempunyai pengetahuan yang kurang.

Tabel 4. Distribusi frekuensi pengetahuan

\begin{tabular}{lcc}
\hline Pengetahuan & N & \% \\
\hline Baik & 25 & $29,4 \%$ \\
Cukup & 39 & $45,9 \%$ \\
Kurang & 21 & $24,7 \%$ \\
\hline Jumlah & 85 & $100 \%$ \\
\hline
\end{tabular}

Pengetahuan responden dalam penelitian ini diuji dengan kuesioner yang terdiri dari 10 pertanyaan mencakup pertanyaan tentang pengetahuan stain gigi pada perokok. Berdasarkan distribusi jawaban responden pada 10 nomor dalam kuesioner, dapat dilihat bahwa pertanyaan yang paling banyak dijawab tahu oleh responden ialah pertanyaan mengenai stain gigi dapat membuat permukaan gigi menjadi kasar dengan jumlah jawaban tahu sebanyak 64 (75,3\%). Jawaban yang paling sedikit di jawab tahu ialah pertanyaan mengenai iritasi yang terus menerus akibat pembakaran tembakau menyebabkan penebalan pada jaringan mulut dengan jawaban tahu sebanyak 21 (24,7\%). 


\section{BAHASAN}

Subjek pada penelitian ini ialah perokok di kelurahan Bahu lingkungan $\mathrm{V}$ yang berjumlah 85 responden. Berdasarkan hasil penelitian, responden yang paling banyak mempunyai pengetahuan cukup yaitu 39 responden (45,9\%), responden yang memiliki pengetahuan baik berjumlah 25 responden (29,4\%), dan yang memiliki pengetahuan kurang berjumlah 21 responden (24,7\%).

Masyarakat di kelurahan Bahu Lingkungan V sangat sering melakukan interaksi sosial baik di dalam kelurahan maupun di luar kelurahan sehingga memungkinkan didapatkan lebih banyak informasi tentang stain gigi. Setiap warga sangat sering berinteraksi dengan warga lain sehingga penyebaran setiap informasi yang di dapat warga bisa sangat cepat sampai pada warga lainnya. Hal inilah yang mempengaruhi pengetahuan responden di kelurahan Bahu lingkungan $\mathrm{V}$ ini yang termasuk cukup.

Sebanyak 61 responden (71,7\%) mengetahui bahwa stain gigi dapat disebabkan oleh merokok. Merokok merupakan hal yang mudah di temui sehari-hari di kalangan masyarakat. Responden dapat mengetahui akan rokok dari media iklan di televisi sehingga melalui penginderaan responden dapat mengetahui bahwa merokok dapat menyebabkan stain pada gigi. Hal ini juga di dukung penelitian yang dilakukan oleh MacGregor IDM bahwa stain gigi dapat disebabkan oleh rokok. ${ }^{6}$

Stain gigi dapat disebabkan oleh merokok, sebanyak 24 responden (28,3\%) tidak mengetahui bahwa stain gigi dapat disebabkan oleh merokok. Dalam hal ini, disebabkan karena responden kurang memiliki pengetahuan tentang rokok dan penginderaan dengan indera penglihatan pada kerabat yang merokok.

Jumlah rokok sangat memengaruhi cepat lambatnya proses pembentukan stain gigi. Sebanyak 39 responden (45,9\%) mengetahui bahwa jumlah rokok sangat mempengaruhi cepat lambatnya proses pembentukan stain gigi. Dalam hal ini responden memiliki pengetahuan tentang proses pembentukan stain pada gigi yang diperoleh melalui kerabat dan penyuluhan-penyuluhan kesehatan gigi dan mulut di puskesmas atau balai kesehatan.

Sebanyak 46 responden (54,1\%) tidak mengetahui bahwa merokok sangat mempengaruhi cepat lambatnya proses pembentukan stain gigi. Pengetahuan merupakan salah satu hal yang menyebabkan responden tidak mengetahui proses pembentukan stain gigi, maupun informasi yang kurang didapatkan dari penyuluhan-penyuluhan atau media.

Lamanya merokok dapat menyebabkan penebalan stain gigi. Sebanyak 51 responden (60\%) mengetahui lamanya merokok dapat menyebabkan penebalan stain gigi. Dalam hal ini, responden mempunyai pengetahuan yang cukup baik mengenai pengaruh rokok dalam proses penebalan stain gigi yang didapatkan melalui informasi dari kerabat yang merokok dan melalui media-media kesehatan maupun sering mengikuti penyuluhan-penyuluhan yang dibuat oleh pemerintah mengenai bahayanya merokok.

Sebanyak 34 responden (40\%) tidak mengetahui lamanya merokok dapat menyebabkan penebalan stain gigi. Responden tidak memiliki atau kurangnya informasi yang didapatkan dari kerabat maupun media-media mengenai merokok yang menyebabkan penebalan stain gigi.

Merokok menimbulkan kelainan rongga mulut, sebanyak 44 responden $(51,8 \%)$ menjawab tahu dan sebanyak 41 responden $(48,2 \%)$ tidak mengetahui bahwa merokok dapat menimbulkan kelainan di rongga mulut. Sebanyak 44 responden (51,8\%) yang menjawab tahu, mempunyai informasi melalui kerabat yang merokok melalui penginderaan, baik indera penciuman, indera penglihatan dan media. Rongga mulut adalah bagian yang sangat mudah terpapar efek rokok, karena merupakan tempat terjadinya penyerapan zat hasil pembakaran rokok yang utama. Komponen toksik dalam rokok dapat mengiritasi jaringan lunak rongga mulut dan menyebabkan terjadinya infeksi mukosa, dry socket dan memperlambat penyembuhan luka. Sebanyak 41 responden (48,2\%) yang 
menjawab tidak tahu kurang memilki pengetahuan baik melalui media-media dan kerabat yang tidak mengenal rokok atau tidak merokok. ${ }^{5}$

Stain gigi terbentuk akibat hasil pembakaran dari nikotin. Sebanyak 43 responden (50,6\%) mengetahui bahwa stain gigi terbentuk akibat hasil pembakaran dari nikotin. Dalam hal ini, responden mendapatkan informasi melalui media di televisi mengenai nikotin dapat menimbulkan stain pada gigi. Nikotin dengan produk dekomposisi khususnya pyridine merupakan substansi penghasil stain gigi yang sering terlihat pada gigi perokok. Unsur tersebut akan membentuk deposit berpigmen yang melekat pada permukaan gigi berwarna coklat sampai hitam. ${ }^{6}$

Sebanyak 42 responden (49,4\%) tidak mengetahui stain gigi terbentuk akibat hasil pembakaran dari nikotin. Dalam hal ini, para responden tidak mengetahui kandungan yang terdapat di dalam rokok yang dapat menimbulkan stain pada gigi serta kurangnya informasi dari kerabat maupun dari media.

Stain gigi dapat membuat permukaan gigi menjadi kasar, sebanyak 64 responden (75,3\%) mengetahui bahwa stain gigi dapat membuat permukaan gigi menjadi kasar. Cukup banyak masyarakat di kelurahan Bahu khususnya laki-laki perokok, sudah lama mengonsumsi rokok sehingga terbentuknya stain gigi pada permukaan gigi dan dapat dirasakan sendiri oleh perokok melalui indera pengecapan. Endapan stain yang menebal dapat membuat permukaan gigi menjadi kasar yang selanjutnya akan menyebabkan penumpukan plak sehingga mengiritasi gusi di dekatnya. ${ }^{7}$

Sebanyak 21 responden (24,7\%) tidak mengetahui bahwa stain gigi dapat membuat permukaan gigi menjadi kasar. Dalam hal ini, responden belum lama mengonsumsi rokok dan belum terbentuk stain gigi pada permukaan gigi sehingga responden tidak bisa merasakan kasar pada permukaan gigi yang diakibatkan oleh stain gigi.

Sebanyak 22 responden (25,9\%) menjawab tahu mengenai iritasi akibat pembakaran tembakau yang menyebabkan penebalan pada jaringan mulut. Dalam hal ini, responden mempunyai pengetahuan yang didapatkan melalui kerabat dengan indera penglihatan, karena gejala ini baru terlihat bila aktifitas seluler bertambah dan epitel menjadi tebal, terutama pada mukosa bukal. Bercak putih tersebut disebabkan karena epitel yang tebal jenuh dengan saliva. ${ }^{10}$ EU Working Group On Tobacco and Oral Health, bahwa penggunaan tembakau dapat menghasilkan efek berbahaya pada jaringan mulut ${ }^{8}$

Iritasi akibat pembakaran tembakau yang menyebabkan penebalan pada jaringan mulut. Sebanyak 63 responden $(74,1 \%)$ menjawab tidak tahu mengenai iritasi akibat pembakaran tembakau yang menyebabkan penebalan pada jaringan mulut. Dalam hal ini, responden kurang memiliki pengetahuan dan informasi mengenai pembakaran tembakau dapat menyebabkan iritasi.

Semua jenis rokok dapat menyebabkan stain gigi. Sebanyak 55 responden $(64,7 \%)$ menjawab tahu mengenai semua jenis rokok dapat menyebabkan stain gigi. Dalam hal ini, responden yang mengetahui bahwa semua jenis rokok yang dikonsumsi dapat menyebabkan stain gigi, baik dari pengalaman pribadi, informasi dari kerabat dan media.

Sebanyak 30 responden (35,3\%) menjawab tidak tahu mengenai semua jenis rokok dapat menyebabkan stain gigi. Dalam hal ini, responden meyakini bahwa tidak semua jenis rokok menyebabkan stain gigi. Karena, responden melihat yang menyebabkan stain gigi pada rokok ialah banyaknya nikotin dan jumlah tar yang biasanya tertulis pada kotak rokok.

Penggunaan tembakau dan kopi dapat menyebabkan stain gigi. Sebanyak 48 responden (56,5\%) menjawab tahu mengenai penggunaan tembakau dana kopi dapat menyebabkan stain gigi. Dalam hal ini, responden mempunyai informasi melalui kerabat dilihat dari penggunaan tembakau dan kopi yang cukup banyak maupun informasi dari media bahwa penggunaan tembakau dan kopi dapat menyebabkan stain pada gigi.

Sebanyak 37 responden (43,5\%) menjawab tidak tahu mengenai penggunaan tembakau dan kopi yang menyebabakan 
stain gigi. Dalam hal ini, responden tidak mempunyai informasi yang baik dari kerabat maupun media tentang penggunaan tembakau dan kopi yang dapat menyebabkan stain pada gigi. Penggunaan produk tembakau, kopi, teh, obat kumur tertentu dan pigmen di dalam makanan menyebabkan terbentuknya stain gigi dan tembakau juga biasanya menyebabkan noda pada permukaan enamel. ${ }^{9,10}$

Stain gigi dapat masuk ke lapisan gigi pada orang yang merokok selama hidupnya dan sukar untuk dihilangkan. Sebanyak 58 responden $(68,2 \%)$ menjawab tahu mengenai orang yang merokok selama hidupnya, stain gigi dapat masuk ke lapisan gigi dan sukar untuk dihilangkan. Dalam hal ini, para responden mengalami sendiri perubahan warna pada gigi yang diakibatkan oleh rokok dan mendapatkan informasi melalui kerabat dengan penginderaan.

Sebanyak 27 responden (31,8\%) menjawab tidak tahu bahwa stain gigi dapat masuk ke lapisan gigi pada orang yang merokok selama hidupnya dan sukar untuk dihilangkan. Dalam hal ini, para responden tidak mempunyai informasi yang benar dan baik dari kerabat maupun dari media mengenai bahaya rokok serta akibat dari rokok.

\section{SIMPULAN}

Gambaran pengetahuan stain gigi pada perokok di kelurahan bahu lingkungan $\mathrm{V}$ yang memiliki pengetahuan baik sebanyak 25 responden (29,4\%), cukup sebanyak 39 responden $(45,9 \%)$ dan kurang sebanyak 21 responden $(24,7 \%)$.

Hasil penelitian diharapkan dapat menjadi dasar untuk mengembangkan studi selanjutnya dan dalam prakteknya dokter gigi dapat memberikan edukasi pada perokok yang memiliki stain gigi. Sebagai informasi dan bahan masukan untuk melakukan penyuluhan tentang stain gigi dan program kesehatan gigi dan mulut.
Perokok disarankan dapat menghilangkan kebiasaan merokok agar tidak terjadi stain gigi yang menyebabkan permukaan gigi menjadi kasar, mengetahui dampak dari merokok dan dapat mempertahankan pengetahuan akan stain gigi. Melakukan penyuluhan dan mengembangkan penelitian ini dengan menghubungkan pengetahuan terhadap stain gigi dengan kebiasaan merokok yang dimiliki oleh responden.

\section{DAFTAR PUSTAKA}

1. Anonimous, Rokok dan kesehatan rongga mulut. [cited 2013 April 17]. Available from URL: http://pdgi-online.com/

2. Anonimous. Bahaya merokok. [cited 2013 April 22] Available from URL: http://www.pdgi-online.com/

3. Reibel J. Tobacco and Oral Diseases. Mediccal Principles and Practice 2003;12(suppl 1).P.22-32.

4. WHO. WHO Report On The Global Tobacco Epidemic. 2008.

5. Kleter GA, Damen JJ, Bujis MJ, Ten Cate JM. Modification of animo acid residues in canious dentin matrix. Journal od dental research 1998;77(3):488-95.

6. Yuni Gumelar. Pewarnaan pada gigi (STAIN). [cited 2013 Juni 04] Available from URL:http://yunigumelar.com/.

7. Berg strom et.al. A 10-year prospective study of tobacco smooking and periodontal health. J periodontal 2000. 71 : 1338-47.

8. Pratomo H, Sudarti. Pedoman pembuatan usulan penelitian bidang kesehatan masyarakat dan keluarga berencana/ kependudukan. Jakarta: Unit Pelaksana Proyek Pembangunan FKM di Indonesia; 1990.

9. Sitepoe M. Kekhususan Rokok Indonesia. Jakarta: PT Gramedia Widiasarana Indonesia; 2000.

10. Pratomo H, Sudarti. Pedoman pembuatan usulan penelitian bidang kesehatan masyarakat dan keluarga berencana/kependudukan. Jakarta: Unit Pelaksana Proyek Pembangunan FKM di Indonesia; 1990. 